\title{
A Tale of Two Referendums: A Comparative Study of the Anti-Amendment Campaign and Together for Yes
}

\author{
Sinéad Kennedy ${ }^{1 *}$
}

Published: March 1, 2022

\begin{abstract}
The 8th Amendment, Ireland's constitutional ban on abortion, may be viewed as a prism through which shifting ideas about women and sexuality in Irish society can be understood. How did Ireland move from being the first country in the world to offer constitutional protection to the 'unborn', to a country that enthusiastically voted to support abortion as a legitimate choice in pregnancy at a time when, internationally, the tide appears to be shifting towards more restrictive abortion regimes? This article offers a comparative study of two referendum campaigns; the feminist-led Anti-Amendment Campaign that organised to oppose the introduction of the amendment in 1983; and Together for Yes, the 2018 campaign to remove the amendment. Focusing on these two campaigns will allow an exploration of how over the course of 35 years' abortion moved from being a one dimensional 'moral' issue to a multi-dimensional political and social question that reflected changing attitudes to sexuality and the role of women in public life. This article examines the political compromises the campaigns made, highlighting the lessons that can be taken forward in order to achieve a more emancipatory discourse of reproductive agency both in Ireland and internationally.
\end{abstract}

Keywords: abortion, feminism, activism political campaigns, reproductive agency, social movement

\section{INTRODUCTION}

The text of the Irish constitution may only be changed by a referendum of the people. In 1983, a small group of conservative organisations and individuals managed to persuade the political establishment to hold a referendum to insert a clause into the Irish Constitution establishing the 'equal right to life' of the 'mother' or pregnant woman and the 'unborn' or foetus. For thirty-five years, the forty-three words that comprised Article 40.3.3', known as the 8th Amendment, would cast a painful shadow over the lives of women and pregnant people living in Ireland. Resistance to the 8th Amendment would shape the struggle for abortion rights in Ireland, culminating in the successful May 2018 referendum which saw its deletion from the Constitution and the legalisation of abortion on request (before 12 weeks) six months later, on 1st January 2019. Over the course of three decades, abortion activists in Ireland have found themselves in a position where they have been forced to adapt their organising to the demands of the referendum campaign (see de Londras, 2020a: 154; Reidy, 2019: 21-22). In 1983, they failed to resist the insertion of the 8th Amendment into the constitution. In 1992, they organised and campaigned around three simultaneous referenda: the right to access abortion information; the right to travel abroad to access abortion services; and to reverse the Supreme Court decision in the X-case ${ }^{1}$ permitting abortion where a pregnant woman's life was at risk from suicide. They managed to achieve the desired result, winning on travel and information and preventing further restrictions on abortion access. In 2002, abortion rights activists once again successfully campaigned to protect the $\mathrm{X}$-case ruling by resisting a further attempt to restrict suicide as a ground for an abortion. Furthermore, multiple 'EU-related referenda had also developed an "abortion-slant", with anti-choice organisers

${ }^{1}$ In the 1992 Supreme Court judgment in the X-case, the four majority judges attempted to reconcile the rights of the 'mother and the unborn', agreeing that, if there was a serious threat to the life of the pregnant woman, including the risk of suicide, abortion was permissible. In the words of Chief Justice, Mr Justice Finlay, 'If it is established as a matter of probability that there is a real and substantial risk to the life of the mother, which can only be avoided by the termination of her pregnancy, such termination is permissible, having regard to the true interpretation of Article 40.3.3.' See X, and McDonagh, S. (1992): 60. 
arguing that amendments to the treaties of the European Union ... would expand EU competencies in a way that “endangered" Ireland's "pro-life" constitution' (de Londras, 2020b: 131). Hence, pro-choice activists in Ireland became necessarily adept at tailoring their activism to the specific demands of referendum campaigning.

The history of pro-choice ${ }^{2}$ activism in Ireland could largely be characterised as reactive ${ }^{3}$. I am not arguing that campaigners were conservative in their approach, but rather that Irish society was dominated by an anti-abortion status quo well into the twenty-first century despite a growing social liberalisation on sexual issues. When not mobilising to resist attempts to further restrict abortion access in Ireland, pro-choice activists concentrated their efforts on supporting women attempting to access abortion services abroad, and, more recently, helping women obtain (illegal) early medical abortions (see Duffy, 2020: 73-75) ${ }^{4}$. This changed in 2012, the twentieth anniversary of the X-case, when activists began to proactively organise to change Irish abortion law, firstly by attempting to implement X-case legislation and later in 2013 with a campaign to remove the constitutional prohibition on abortion. To achieve this, a referendum was required and feminists and activists who supported the demand for 'free, safe and legal abortion' came under internal and external pressure to temper demands and moderate their expectations to win a referendum campaign once again.

This article offers a comparative study of feminist interventions into two referendum campaigns: The AntiAmendment Campaign that organised to oppose the introduction of the amendment in 1983, and Together for Yes, the 2018 campaign to remove the amendment and legalise abortion in Ireland. It should be noted that this analysis, in part, emerges from my own position as a pro-choice abortion activist in Ireland for over two decades, and from my direct involvement in the Together for Yes Campaign ${ }^{5}$. I utilise, where possible, academic and other accounts by the activists involved in these campaigns in order to develop an analysis that emerges from the perspective of what the legal academic/activist Fiona de Londras (2021a: 126-7) terms

the strange insider/outsider position that both enforces an ethical obligation for critical self-reflection and potentially blinkers one from some important insights.

Focusing on two different referendum campaigns allows us to understand how over the course of thirty-five years' abortion in Ireland moved from being a one dimensional 'moral' issue to a complex and multi-dimensional political, social and cultural question that reflected changing social attitudes to sex, sexuality, the body, and role of women in public and private life. It will also allow us to understand how the particular demands of a referendum campaign created external and internal pressures on pro-choice activists to modify feminist demands to ensure that their arguments were palatable to a broad electorate who ultimately got to determine the extent of women's and pregnant people's bodily autonomy. The article will conclude by examining the political compromises that both campaigns felt compelled to make, and the lessons that feminists can take forward from this if we are to achieve a more emancipatory discourse of reproductive agency both in Ireland and internationally.

\section{THE 1983 REFERENDUM}

By the early 1970s, the impact of the women's movement on Irish society was impossible to ignore. Women began organising to demand and achieve greater economic, social and political independence; they were beginning to pursue education for longer, assumed occupations traditionally understood to be the preserve of men, socialised in pubs, played sports and acquired growing economic independence, allowing them to rewrite the cultural conventions of what was considered appropriate behaviour for women (Inglis, 2003: 140-1). The initial focus of the late twentieth century women's movement was undoing much of the discriminatory legislation that was introduced by the post-independent state and by the end of the decade the movement had achieved significant

\footnotetext{
2 The use of the term 'pro-choice' by abortion rights activists in Ireland has a long and complicated history. As I will argue in this article many activists campaigning for greater access to abortion in the hostile political and cultural climate of Ireland in the 1980s and 1990s were often reluctant to use the term to describe their activism for fear of being labelled extremist. I have used the term in this article as a widely accepted term to describe those who support the legalisation of abortion while recognising that many of those involved in the movement especially in the early 1980s and 1990s would not have used the phase to describe themselves or their activism.

3 One key exception to this was in June 2001 when a number of Irish abortion activists collaborated with the Dutch NGO Women on Waves to bring a ship with an on-board medical treatment room with the aim of offering medical abortions. For an account see Women on Waves (2001) and for a statement by the Irish activists involved see Women on Waves Ireland (2001).

${ }^{4}$ Medical abortion pills were available online for women living in the Republic of Ireland and Northern Ireland from Women on Web https:/ / www.womenonweb.org/ Women Help Women https://womenhelp.org. For a comprehensive discussion of the use of the abortion pill in Ireland to self-induce an abortion see Sheldon (2016).

${ }^{5}$ I was co-founder with Ailbhe Smyth of the Coalition to Repeal the Eighth Amendment and served as a member of the TFY executive and I was also the head of research for the TFY campaign.
} 
gains, particularly around work and pay inequality (see Connolly, 2003: 89-110). However, the effects of these changes were far more profound than simply legislative: women began to reimagine not only the country they lived in, but, crucially, the way they understood themselves. As Tom Inglis (2003: 140) writes:

The development of women's self-awareness and confidence was something that was happening all over Ireland in the 1970s and 1980s. Irish women were struggling to break free from the language of Catholic Church teaching with its emphasis on motherhood and self-denial and to find a new language and way of thinking, writing and talking about themselves. Women began to form groups, to counsel and advise themselves and to set up their own education courses. They were beginning to reflect critically about themselves, and the families, communities and society in which they lived.

However, as we will see, this transformation was neither seamless nor uncontested and many men, and some women, challenged, resisted and resented women's struggle for equality.

In their 1971 manifesto, Chains or Changes? The Civil Wrongs of Irish Women, the group Irish Women United identified a range of inequalities that beset Irish women. It called for unmarried and separated women to be entitled to state benefits; for women in the civil service to be permitted to retain their jobs after marriage; for equal pay for equal work; for reform of family law to protect women, particularly in cases of marital breakdown; for an end to the stigmatisation of women and their children who were born outside of marriage. However, it is noteworthy that only after 32 pages, towards the very end of the manifesto, the absence of childcare facilities and access to contraception is mentioned under the heading 'Incidental Facts'. In her reflections on the period, feminist activist Ailbhe Smyth noted that:

[i]n retrospect, it seems ironic that a section dealing with such issues as the absence of childcare and contraception should have been entitled 'Incidental Facts' (...) The focus on the nuclear family, on liberal themes such as equal rights and educational opportunities, the low-key treatment of contraception and the absence of any reference to abortion, the lack of any analysis of sexuality or of sexual politics, these all seem surprising now (...) (1993: 252-3).

Over the course of the 1970s however, contraception would emerge as a key battleground in the struggle for equality and women's organisations were at the forefront of the campaign for legalisation. By the end of the decade, legal access to contraception was achieved albeit for what the legislation termed 'bona fide family planning'. To access contraception, the highly restrictive, and largely unworkable act, required the individual to have a medical prescription and it was then dispensed on the good faith basis that it was only for 'family planning' reasons. Charles Haughey, the then Minister for Health, admitted from the outset that the purpose of the Bill was not to increase the availability of contraception but to restrict it, declaring the bill to be providing 'an Irish solution to an Irish problem' (Haughey, 1979). Despite consultation with the hierarchy of Irish Catholic in the run-up to the bill's drafting, the reaffirmation of the ban on abortifacients, and the inclusion of a conscience-clause for doctors and pharmacists who opposed artificial contraception, conservative forces within the State still interpreted the legislation as a major defeat. They were not wrong: arguably, it did represent the first substantial break, at least in the area of social legislation, between the Irish State and teachings of the Catholic Church on sexuality and the family, but it also led to the emergence of an alliance between Catholic and conservative groups with abortion as their core campaigning issue ${ }^{6}$.

At first, it may appear difficult to understand the motivation behind the Catholic, conservative right wing's desire to introduce a so-called 'pro-life' amendment into the Irish Constitution. Firstly, abortion was illegal in all circumstances in Ireland, and had been since the 1861 Offences Against the Person Act, which was incorporated into the legal apparatus of Irish State following independence in 1922. The Health (Family Planning) Act of 1979 also patently reasserted that sections 58 and 59 of the 1861 Act do, in fact, constitute abortion law in Ireland. Secondly, while abortion laws were being liberalised in Europe and the United States, there was no significant campaign evident in Ireland to legalise abortion (see Smyth, 2002). The Women's Right to Choose Group (WRCG), one of the first groups to openly campaign for access to abortion, had begun meeting in 1979 but abortion politics was mainly confined to the ideological left and was considered relatively marginal within the broader women's movement. However, the agenda of the conservative movement from the outset was more political and ideologically ambitious than simply reinforcing Ireland's abortion ban; contraception and abortion were understood from the beginning as simply 'one front in a wider religious war' (O'Toole, 2014). The conservative movement's key political agenda was always to maintain the status quo and prevent what they understood to be as the imminent threat of secularisation and liberalisation to Irish society.

${ }^{6}$ For an overview of the debate around the legalisation of contraception in Ireland in the 1970s, see Ferriter (2009: 360-406) and Hug (1999: 76-139).

(C) 2022 by Author/s 
By the late 1970s, conservative forces had already attempted to mobilise on a variety of issues to manage and contain the political and social instability of the Irish State at the beginning of the 1980s. These efforts, and the subsequent 'pro-life' campaign, were part of a deliberate countermovement against progressive social change in Irish society more generally, and specifically, against the modest gains of the women's movement (see Connolly, 2003: 156-159; O'Reilly, 1992: 10-15). Ideologically, it may be understood in terms of what Susan Faludi has characterised as a 'backlash'7. The conservative right emerged as 'a defensive reaction to the process of change' but achieved momentum during the 1970s, thereby transforming themselves into an 'offensive force' demanding and securing support from major political parties (Barry, 1992: 113). So, for example, in 1976 they attempted to organise against the formation of a multi-denominational primary school in the affluent Dalkey suburb of Dublin, arguing that it was a fundamental challenge to the Catholic dominance of the Irish Education system. Later, a group calling themselves the 'League of Decency' organised a series of public campaigns against 'immoral' TV shows and family planning clinics ${ }^{8}$. They even opposed a small state grant that was given to the Dublin Rape Crisis Centre. All of these initiatives failed to receive any meaningful support; it was only around the issue of abortion that they managed to gain any traction.

Members of the religious and conservative right had long feared that abortion might become legal in Ireland at some point in the future. Speaking at the founding conference of the Irish 'pro-life' movement in January 1981, leading activist Denis Barrow argued that while it was 'unlikely that such an action would succeed at the present time ... it could conceivably succeed three or four or seven years hence' (cited in Heskett, 1990: 3). These concerns were aggravated by Ireland's decision to join the EEC (now EU) in 1973 and, that same year, most particularly by the United States' Supreme Court decision in Roe v. Wade9 to legalise abortion. The source of their concern lay in the legal reasoning behind the case: the US Supreme Court stated that a constitutional right of privacy was 'broad enough to encompass a woman's decision whether or not to terminate her pregnancy', a ruling that was an extension of an earlier 1965 US Supreme Court privacy ruling on the right to contraception (Sanger, 2017: 5). Irish conservative circles began to fear that at some point, a case would arise in the Irish Supreme Court where the Court would decide that the right to privacy in marital affairs not only included a right to contraception-as the Court ruled in the $1974 \mathrm{McGee}^{10}$ case-but a right to abortion as well. It was determined that what was required was a provision in the constitution that would ban abortion outright, making it impossible for the Supreme Court to ever interpret a right to abortion within the Irish Constitution (see Lord, 2015: 93-96).

In April 1981, following several months of discussions among religious and conservative groups ${ }^{11}$, the Pro-Life Amendment Campaign (PLAC) was established with the aim of lobbying political support to hold a referendum to insert a 'pro-life' clause into the Constitution, a task they proved to be seriously adept at. In November 1982, the first draft of the amendment was prepared by a centre-right Fianna Fáil government under the leadership of Charles Haughey. Soon after, Fianna Fáil lost power but this did little to slow the advancement of PLAC's support. In February 1983, a coalition government led by the other leading centre-right Irish political party, Fine Gael, announced its intention to hold a referendum in September 1983 using the wording advocated for by PLAC.

\footnotetext{
${ }^{7}$ Writing about the cultural war against women in the USA in the 1980s, Susan Faludi characterised 'backlash' as 'an attempt to retract the handful of small and hard-won victories that the feminist movement did manage to win for women. This counterassault is largely insidious: in a kind of pop-culture version of the Big Lie, it stands the truth boldly on its head and proclaims that the very steps that have elevated women's position have actually led to their downfall' (Faludi, 1991: 9-10). O'Reilly (1992) also uses the term 'backlash' in her analysis of the rise of the anti-abortion movement in Ireland.

${ }^{8}$ League of Decency is an Irish off-shoot of the National [or Catholic] Legion of Decency established in United States in 1934. One of their first public actions in Ireland was to write to Taoiseach [Prime Minister] Éamon de Valera in September 1997 requesting an interview: 'This letter is written as a despairing cry from a frustrated body of Catholics to clean-up on indecent books, picture-post cards, films etc. ... we have done almost all we can-we are still storming heaven —within the law to combat the imported press and film evils, but are being thwarted by the very law itself and so find ourselves foiled to remove sources of scandal from public display'. (Ferriter, 2009: 307-308). They continued to be active in the 1970s and 1980s (see Ferriter, 2009: 465, 470).

${ }_{9}$ Roe v. Wade, was the 1973 U.S. Supreme Court decision that legalised abortion in the United States. The Court ruled that the Constitution of the United States protects a pregnant woman's freedom to choose to have an abortion without excessive government restriction. See Roe v. Wade, 410 U.S. 113 (1973).

${ }_{10}$ McGee v. The Attorney General [1974] IR 284. The McGee case did lead to the limited legalisation of contraception although it would be a further six years before legislation was introduced.

${ }^{11}$ Founding members of PLAC include Congress of Catholic Secondary School Parents' Association; Irish Catholic Doctors Guild; Council of Social Concern; Guild of Catholic Nurses; Guild of Catholic Pharmacy; Catholic Young Men's Society; St. Thomas More Society; Responsible Society; Society for the Protection of Unborn Children; Irish pro-Life Movement; National Association of the Ovulation Method - Ireland; St Joseph's Young Priests' Society; and the Christian Brothers School Parents' Federation. The Irish Association of Lawyers for the Defence of the Unborn affiliated later in May 1981. The Irish Nurses Association, Muintir na Tire, Pax Christi and Christian Life Communities conveyed messages of support. See Heskett (1990: 1-37); O’Reilly (1992: 55-58, 62-65).
} 


\section{The Anti-Amendment Campaign}

When the Women's Right to Choose Group (WRCG) began meeting in 1979, abortion was not a political issue in Ireland, nor was it understood or prioritised as a critical feminist issue in the way that it had been by the 1970s women's movements in Europe and North America. While abortion was discussed and debated in some of leftwing sections of the movement, it was decided tactically, amid the political struggle around contraception at the time, that to also begin advocating for abortion would risk a conflation of abortion and contraception (see Connolly and O'Toole, 2005: 68-70). The reality of abortion in Ireland was rarely discussed despite it being a real, if unacknowledged, aspect of women's lives. The legalisation of abortion in Britain following the introduction of the 1967 Abortion Act, saw Irish women silently, and often covertly, travel in their thousands every year to access terminations abroad, a fact largely and conveniently ignored by the campaign to introduce the anti-abortion constitutional amendment. Between 1968 and 1983, at least 30,560 ${ }^{12}$ Irish women travelled to Britain to obtain an abortion with numbers climbing steadily year by year. These official figures of women travelling for abortions were published annually (by the Department of Health in England and Wales) and subsequently reported every year in Irish newspapers without comment.

In 1979, the WRCG began politically agitating around access to abortion, holding public meetings, seminars, writing articles and speaking to the media. The following year, they began offering support to women who needed referrals to British abortion clinics through the Irish Pregnancy Counselling Centre ${ }^{13}$. In 1981, they published a pamphlet, Abortion: A Choice for Irish Women, advocating for access to abortion as a necessary choice for women. This pamphlet became one of few sources of abortion information available in Ireland as abortion information was tightly regulated and subject to the 1967 Censorship of Publications Act (see Kennedy, 2020: 118-122). Shortly before the launch of PLAC, WRCG held a packed meeting in Liberty Hall, Dublin. The meeting was invaded by the anti-abortion group SPUC ${ }^{14}$ who shouted verbal abuse at the speakers and attendees. Activist and founding member of the WRCG, Mary Gordan, wrote of the 'unnerving' nature of the experience for the group:

It made us realise that we were not going to be allowed to continue to operate unhindered. SPUC had been set up in Ireland in June ' 80 ... but until the Liberty Hall meeting, we had not actually experienced them in operation. We had tended to reject them as arch-[C]atholic fanatics, but it was now becoming clear that they were very well organized and that their message had strong appeal. They were using the existence of our group to create the illusion of a serious threat against which the up-to now latent antiabortionism of Irish society need to be mobilized (Gordan, 1984: 11).

The launch, a month later, of PLAC and the willingness with which Irish politicians appeared to acquiesce to their demand for a referendum took feminist activists by surprise and forced them into a reactive position from which arguably they never managed to escape.

From the beginning, one of the key strategic debates among feminists was how PLAC should be opposed: should it be opposed on the basis of the WRCG's pro-abortion position, or should a more 'liberal', broad-based anti-amendment campaign be established? Activists initially proposed setting up a Women's Right to Choose Campaign, which would also be open to men, to organise in opposition to PLAC, but after several months of internal discussions and debate others began to argue for a more broad-based campaign approach that would oppose PLAC on a less radical basis and create an opportunity to draw in a wider layer of people. Reflecting on the debates from this time, Mary Gordon, a founding member of the WRCG and a key activist from the period, argues that these positions were unnecessary and damaging to the campaign from the beginning:

Looking back ... it is now obvious that the decision did not have to be an either/or one. A broad-based anti-amendment organisation was necessary to oppose PLAC, and the WRCG were correct when they assessed that the onus was on us to set one up. But the existence of a broad-based liberal campaign did not preclude independent right to choose opposition to the amendment, and so the split that occurred seems, in retrospect, to have been unnecessary and unfortunate (1984: 14).

\footnotetext{
12 This figure is calculated from public anonymous data collected by the UK Department of Health Statistics and it refers to women resident in Ireland who travelled to both England and Wales to access abortion services. It is widely accepted that this figure is an underestimation as it does not include women who travelled to Scotland or to other European Countries. The figure does not include women who did not disclose an Irish address to clinics/hospitals in England and Wales, which, according to clinics such as BPAS, was something that women frequently did to protect their confidentiality or to reduce costs by avoiding the mandatory overnight stay that clinics required of non-resident women.

${ }^{13}$ For a fuller discussion of this period, see activist Ruth Riddick's pamphlet (4-6).

${ }^{14}$ SPUC: Society for the Protection of Unborn Children, an offshoot of the British organisation of the same name, was a radical anti-abortion group that operated on the frontlines of abortion campaigning in Ireland for many years. Many of their members were active in PLAC though not, it appears, at a leadership level.
} 
Following Taoiseach [Prime Minister] Charles Haughey's announcement in the Spring of 1982 that he intended to call a referendum based on a version of PLAC's wording forced a decision ${ }^{15}$. In April 1982, the Anti-Amendment Campaign (AAC) was established, with a campaign name, the five-point basis of opposition to the amendment and the nature of the campaign itself-a broad front to which organisations and individuals could affiliate-all agreed over the course of two meetings. The pro-abortion arguments advocated for by the WRCG were marginalised in favour of a more centralist or liberal approach. The AAC's position on the amendment was encapsulated within the following five-point platform:

1. The proposed amendment would do nothing to the solve the problem of unwanted pregnancies in Ireland.

2. The amendment would allow for no exception even in cases where pregnancy severely threatens a woman's health or where pregnancy results from rape or incest.

3. The amendment seeks to enshrine in the Constitution the teaching of one religious' domination. Leaders of Protestant Churches and the Jewish Community have expressed grave reservations about the matter.

4. The proposed amendment will impede further public discussion and possible legislation on abortion.

5. At a time of severe unemployment, when one third of the population is living on or below the poverty line, the proposed amendment is an irresponsible waste of public funds ${ }^{16}$.

The AAC would later refine their focus towards points one, three, and five. Points two and four increasingly came to be viewed as too radical and became a source of heated debate and friction over the course of the campaign (see Gordan, 1984: 14-17; Heskett, 1990: 85-89). Certainly, in the early stages of the campaign, the AAC appeared determined to emphasise the religious and sectarian nature of the amendment and downplay the question of abortion itself. For example, in a letter to The Irish Times, Anne O'Donnell, from the AAC's steering committee, argued, 'The Roman Catholic hierarchy will have to listen to those who do not share their views on the proposed constitutional amendment if they truly believe in ecumenicism or pluralism,' and went on to emphasise the Protestant Churches' opposition to the amendment (O'Donnell, 1982). This argument failed to gain significant traction and, in an attempt to refocus attention on women, the campaign's central tenet shifted to arguing that the amendment would endanger women's lives (health was rarely mentioned). Although, as we will see, women would lose their lives because of the 8th Amendment, the argument simply did not carry enough weight at that time and was constantly being subsumed into moral and legal-medical debates on the wording of the amendment ${ }^{17}$.

Both sides were debating the necessity of an anti-abortion amendment in a country where abortion was already illegal, and where there was little, if any, debate on the issue of abortion itself and why it is necessary that women have access to abortion ${ }^{18}$. Indeed, so taboo was the subject that even the word 'abortion' was largely absent from the discussion with both sides employing the term 'the substantive issue' instead of the word abortion (see Cacciaguidi-Fahy, 2005: 141-3). Activists working in the AAC also had little experience talking about abortion. The academic, Pauline Jackson, an activist with AAC at the time, writes of the period:

Most women had never discussed abortion in public-indeed, not outside an intimate circle of friends! None knew how to make a speech on the subject. None of the left-wing political parties would agree at first to join the campaign. It seemed for a time that every official legitimate political faction was going to support an amendment to the constitution to 'give an absolute right to life of the foetus' (cited in Connolly, 2003: 164).

On the ground, campaigners were met with open hostility and they struggled against the simplicity of PLAC's message: 'if you are against abortion, support the amendment'. In comparison, the AAC's messaging was varied and complex and many involved in the campaign were at pains to emphasise their own opposition to abortion. For example, in the final stages of the campaign some of the more conservative sections of the AAC began to argue for a No vote based on opposition to abortion. The AAC in Waterford, for example, produced a leaflet

\footnotetext{
15 The amendment which became Article 40.3.3 of the Irish Constitution stated that: 'The State acknowledges the right to life of the unborn and, with due regard to the equal right to life of the mother, guarantees in its laws to respect, and, as far as practicable, by its laws to defend and vindicate that right.'

16 Source: A 1982 leaflet from the Anti Amendment Campaign outlining their reasons for opposing the holding of a Referendum. The leaflet has the founding statement of the Campaign as well as a list of public figures and groups that backed the campaign.

${ }^{17}$ For an overview of the types of arguments advanced by the AAC, see The Irish Times account of a Campaign press conference: "Abortion Amendment "dodges issue". The Irish Times, 10 December 1982: 15.

${ }_{18}$ Probably the most explicitly pro-choice statement made by the AAC was a letter sent by Lorraine Scully to The Irish Times on behalf of the steering committee. She writes: 'Over the past few months, correspondents have discussed the legal, medical, theological and philosophical aspects of the proposed amendment ... Although these arguments are fundamental to an informed and balanced opposition to the amendment, they do not relate to the practical problems of women living in present day Ireland ...' (The Irish Times, 15 July 1982). From this point onward, if one examines the press statements issued by AAC, they all largely emphasise the politico-constitutional issues and ignore abortion itself.
} 
stating that ' $89 \%$ of local doctors' and ' $80 \%$ of local lawyers' were voting No to the Amendment based on technical legal-medical arguments, before concluding: 'No to Abortion. No to Amendment'19.

Women's experiences of pregnancy and abortion were not just absent but actively omitted from public discussions on the amendment. For example, in 1981, the journalist and activist, Mary Holland, became possibly the first Irish woman to stand up in public and speak about her abortion. However, she stood up, she stood alone and was forced to endure a concerted hate-campaign which saw her vilified in newspapers, condemned from church pulpits around the country, and to receiving an endless stream of hate mail. Her then partner, fellow journalist and activist, Eamonn McCann, described what she had to endure at the time:

Mary was chair of the Anti-Amendment Campaign. She wasn't just shouted at in the street, she was followed into functions and subjected at close quarters to spittle-flecked tirades delivered into her face. At one gathering, she apologised for leaving early, explaining that she had to get home for a birthday party for one of our children. A red-faced pro-lifer was on his feet in a flash: 'The child you murdered won't be at that party.' Cue a chorus of jeers as she walked towards the door. Letters arrived not just at The Irish Times, where she worked, but at our home, wishing all manner of personal disasters upon her and promising hell-fire for the infant mortal life ended (McCann, 2016).

Holland's treatment would serve as a clear and powerful warning to any woman considering taking a similar public stance. And it succeeded: women talking about their abortions in public was an exceedingly rare event in Ireland until the Repeal campaign emerged decades later. The public vacuum created by the absence of women's voices and experiences of abortion in the debate was filled by legal-medical debate as 'experts' - the doctors, lawyers and priests - debated the finer points of the morality of abortion. By the end of the intense campaign,

[t]he only result was that the vision of babies being killed in the womb was stronger in the minds of the Irish than the potential danger in which the amendment would put women (Hug, 1999: 154).

Support for the amendment was unambiguous with two thirds of the electorate supporting it with a $66.9 \%$ majority, at a turnout of just $53.6 \%$. It was a devastating defeat, and for many confirmed once again the marginalisation and invisibility of women in Irish public life.

Emboldened by the referendum victory, anti-abortion campaigners switched their target to censoring abortion information, by canvassing for prosecutions against organisations providing abortion advice or banning information such as provided at student unions and women's health clinics. As one anti-abortion activist put it at the time:

in order to defend the right to life of the unborn, we must close the abortion referral agencies which are operating in Dublin quiet openly and underneath the eyes of the law (cited in Hug, 1999: 157).

This led to a series of prolonged legal cases that would ultimately be decided by the European courts. Once again, the experiences of Irish women remained invisible with theological and legal arguments continuing to supersede the personal experiences and stories of women, and the right to have an abortion struggled to get a hearing as prochoice abortion campaigners were forced to concentrate their efforts on ensuring women had access to the necessary information so they could travel to Britain for abortions. However, in February 1992, nine years after the 8th Amendment was introduced, the Irish Supreme Court (X case) would have to make a specific judgement about the circumstances under which a life-saving abortion could be performed in state and define exactly what constituted 'a real and substantial risk to life'. Faced with all the complexities of a real-life case involving a 14-yearold suicidal rape victim, the anti-abortion consensus collapsed, and conservative forces discovered that they were unable to hold back the tide of secularisation that was relentlessly making its presence felt in Irish society; the X case had irrecoverably changed public opinion on abortion, although it would be a further twenty-five years before the 8th Amendment was removed from the constitution ${ }^{20}$.

\section{Lessons Learnt}

The nature of the AAC's referendum campaign was the subject of intense debate among activists from its inception. The WRCG's meetings to discuss the establishment of AAC were dominated by debates on how best to defeat PLAC and there was, from the beginning, clear divisions between 'radicals' who advocated for a proabortion perspective and 'moderates' who favoured a more liberal position with the latter's position coming to dominate. While these debates within the abortion movement were certainly not unique to Ireland (see Brown,

\footnotetext{
${ }^{19}$ Leaflet produced by the AAC Wexford.

${ }^{20}$ For an account of the shift on the issue, see feminist and activist Ailbhe Smyth's ground-breaking 1991 edited collection The Abortion Papers for a range of perspectives on abortion in Ireland in the 1980s.
} 
2019: 62-83), the Irish abortion debate in the early 1980s was something of an exception. In Europe and North America, a much-rehearsed strategy had been employed-restrictive abortion laws were attacked through a combination of protest movements, parliamentary action and legal test cases challenging the rigidity of abortion laws. The emergence of PLAC, who were seeking to strengthen those same laws by alleging that feminists and proabortion groups were attempting to introduce abortion, made such a strategy near impossible in a Catholicdominated Ireland. Therefore, the moderate argument easily dominated within the AAC. Furthermore, as discussed above, the political climate in which the AAC operated was intensely hostile and from the outset it was clear that political terrain of the referendum campaign would be determined and dominated by the PLAC. In those circumstances, a pro-abortion argument was unlikely to break through and win the referendum. However, as some campaigners argued at the time ${ }^{21}$, if the abortion argument had been faced honestly and openly addressed by the AAC, the campaign may not have won, but it may have succeeded in creating the space for a pro-abortion position to be further advanced and developed in Ireland and, crucially, for the voices and experiences of Irish women to become part of the debate. The loss of this referendum meant that it was impossible for abortion to be made legal in Ireland without another referendum. Furthermore, the nature of the AAC campaign set back and demoralised the pro-abortion movement, making it harder for the movement to respond and argue for a position that it had previously denied or minimised.

\section{THE 2018 REFERENDUM CAMPAIGN}

The political terrain on which the 2018 referendum campaign to remove the 8th Amendment from the Constitution was fought was dramatically different. In the three decades following the introduction of the 8th, feminists and campaigners continued to agitate and organise around access to abortion but increasingly in a cultural climate that would be characterised less by hostility, and more by indifference. Women in their thousands every year exercised their own agency by travelling abroad for abortions, although it is important to note that this option was only available to those with both the means and the ability to travel (see Earner-Byrne and Urquhart, 2019: 105-109). Access to abortion was further democratised with the establishment in 2005 of Women on Web which offered a safe and more affordable option of a medical abortion, albeit an illegal one ${ }^{22}$. Abortion mobility and the importation of illegal abortion pills were quietly tolerated but rarely discussed realities of life in Ireland and functioned essentially as a safety-valve, easing the pressure on the politicians to act (see Side, 2020: 17-18). Despite numerous commitments to the contrary, six successive Irish governments failed to introduce legislation in line with the X case, the consequences of which would later prove fatal. In 2012, in the run-up to the thirtieth anniversary of the $\mathrm{X}$ case, activists established Action on $\mathrm{X}$, a campaign to force the introduction of $\mathrm{X}$ case legislation, working with a number of left-wing members of the Irish parliament (see Daly, 2015: 263-269) 23. Later that Summer, the first March for Choice towards a new offensive mode of operating would be held (see Spillane, 2015: 164). Activists began to self-consciously argue that abortion was not simply involving hard and tragic cases, but a 'personal choice' and 'available on request'. Later that year, the Abortion Rights Campaign, was established with the aim of fighting for the introduction of free, safe and legal abortion (see Doherty and Redmond, 2015: 270). The name of the campaign is particularly significant here given the previously discussed suppression of the word 'abortion' even among campaigners ${ }^{24}$. Six years later, abortion would be legally available in Ireland.

\section{Repeal in Context}

In October 2012, Savita Halappanavar, an Indian woman living in Ireland, presented herself at a Galway Hospital miscarrying at 17 weeks. Doctors felt that due to the presence of a foetal heartbeat, they could not treat her, citing the 8th Amendment (Holland, 2013: 81). This subsequently proved fatal when she died of septicaemia. The death of Savita provoked a wave of national and international horror at Ireland's punitive abortion regime. Thousands gathered in silent vigil outside the Irish Parliament once the story broke in the media and days later

${ }^{21}$ See Gordan (1984: 22-27). In May 1982 at the launch of WRTG, socialist Goretti Horgan argued 'that it was wrong that the debate should concentrate solely on the confessional nature of the Constitution ... We are worried about the extent to which the rights of women might be ignored' (The Irish Times, 6 May 1982).

22 See Women on Web https://www.womenonweb.org/en/page/521/who-we-are. Abortion was illegal in Ireland under the 1861 Offences Against the Person Act which criminalised women who 'procure a miscarriage'. It was also makes it a crime to assist a woman to 'procure a miscarriage'. The punishment in both cases is life imprisonment.

${ }^{23}$ In April 2012, Clare Daly TD introduced a Private Members Bill to implement the X case. The Bill was rejected (110 TDs voted against the Bill, and 20 TDs voted in favour). The Bill was the first abortion legislation introduced in the history of the Irish state.

${ }^{24}$ Grainne Griffin, a founding member of ARC noted: 'When we named ourselves the Abortion Rights Campaign it was actually quite a controversial decision because abortion was not a word that people liked saying in public' (Griffin cited in Goodman, 2018). 
tens of thousands marched in Dublin, with simultaneous demonstrations across the country, chanting Never Again'. The political establishment, who had managed to successfully maintain a conspiracy of silence around abortion since the $1992 \mathrm{X}$ case, found itself under enormous pressure to at least appear to act. Still fearful of vocal anti-abortion lobby, political parties supported the introduction of the Protection of Life During Pregnancy Act (PLDPA, 2013)-essentially X case legislation-permitting abortion where the life of the pregnant woman was at risk, although controversially it created an arbitrary and unworkable distinction between physical and mental health. It also copper-fastened the criminalisation of abortion with doctors and women who had illegal abortions facing criminal penalties of up to 14 years in prison (see de Londras and Enright, 2018: 15-32).

The death of Savita Halappanavar and the unworkability of the PLDPA galvanised the pro-choice movement into mobilising an intense campaign to pressure the government into calling a referendum to repeal the 8th Amendment. Activists began mobilising through protests, art, street theatre and various forms of direct action. In 2013, a coalition of activists, political organisations and NGOs established the Coalition to Repeal the Eighth Amendment to protect and respect women's lives, health and choices. The organisation sought to develop a broadbased, critical mass of groups and organisations who a held a variety of different positions on abortion but who would all agree to come together in support of repealing the 8th. The Repeal movement was further emboldened when on 22 May 2015, the Irish electorate voted overwhelmingly 25 to legalise same-sex marriage and Ireland became the first country in the world to bring in same-sex marriage by a popular vote. For many abortion activists, this pointed to a dramatic sea-change in Irish culture and society and the positive, joyful tone of Yes Equality ${ }^{26}$ began to be seen as a model for a potential future Repeal campaign where abortion could be framed as a positive good for women and Irish society more generally. In 2016, a group called 'Strike for Repeal' organised around a global demand for women to strike on 8 March, which is International Women's Day. Their actions inspired thousands of young people across the country to walk out of schools and Universities and they succeeded in shutting down Dublin city centre for a number of hours (see Edwards and Flaherty, 2017; Field, 2018). As a direct result of this intense campaigning by pro-choice activists, a referendum on repeal continued to intensely feature on the political landscape, reaching a point where it became politically damaging for politicians to continue with their cautious and indifferent approach ${ }^{27}$.

\section{The Together for Yes Campaign}

One obvious difference for abortion activists campaigning in 2018 was that they were operating in a more favourable political environment. They did not get to design the referendum, like PLAC had in 1983, but the political establishment had acceded to campaigners' demands for a referendum. From the beginning, pro-choice abortion activists across the political spectrum agreed that a successful campaign would require a centrally organised and nationally co-ordinated operation with clear messaging and a co-ordinated strategy. The model that many began to favour was the highly successful 'Yes Equality' campaign ${ }^{28}$. In this context, three organisations-the National Women's Council of Ireland (NWCI), the Coalition to Repeal the Eighth Amendment (Coalition) and the Abortion Rights Campaign (ARC)-came together in January 2018 to establish 'Together for Yes', the National Civil Society Campaign to Remove the Eighth Amendment ${ }^{29}$. The idea was to create a broad and diverse campaign rooted in the experiences of women and their families, which focused on achieving laws and services, informed by best medical practice that responded to the needs of women. Collectively, the three organisations had a strong public profile on abortion, as well as considerable campaigning and mobilisation experience. A determining factor in coming together was that each organisation committed to share human and financial resources, political expertise, organising and research capacity, and their considerable grassroots and mobilisation support (see Griffin et al., 2019: 96-100).

The three organisations spent several weeks working together, designing an effective campaign structure led by three co-directors, one from each organisation: Grainne Griffin (ARC), Orla O'Connor (NWCI), and Ailbhe Smyth (Coalition). The campaign was subsequently expanded to include the Irish Family Planning Association (IFPA) who were probably the longest campaigning organisation in Ireland on reproductive rights, beginning with contraception back in the $1970 \mathrm{~s}^{30}$. As we saw with the AAC in 1982/3, within-broad based campaigns it tended to be the more liberal voices that come to dominate, often at the expense of the more radical tendencies. The

\footnotetext{
$2562.07 \%$ of the electorate voted in favour of the constitutional amendment to legalise same-sex marriage.

${ }^{26}$ Yes Equality: The Campaign for Civil Marriage Equality was the principal organisation that campaigned for a Yes vote on marriage equality in 2015. For an overview of the 2015 Marriage Equality referendum campaign see Mulhall (2015).

${ }^{27}$ For an overview of this period of activism, see Carnegie and Roth (2019).

${ }^{28}$ A number of key Together for Yes activists, including Ailbhe Smyth and Denise Charlton, played significant roles within Yes Equality.

${ }^{29}$ For details of the Together for Yes Campaign, see the website: https://www.togetherforyes.ie.

30 For an overview of the IFPA's work see: A Health and Rights Approach to Abortion in Ireland https://www.ifpa.ie/sites/default/files/ifpa_submission_to_the_citizens_assembly.pdf.
}

(C) 2022 by Author/s 
nature of referendum campaigns tends to exacerbate this, as they require campaigns to orientate themselves towards the middle ground in order to attract undecided or moderate voters. As many of the pro-choice groups organised themselves into Together for $\mathrm{Yes}(\mathrm{TfY})$ as a single, official campaigning organisation, the tensions between the desired outcome (largely, repeal, followed by decriminalisation and professional regulation only) and the perceived demands of a constitutional referendum (the desire to be moderate and reassuring in the hope of winning 'the middle ground') became clear from the outset.

One of the first and most difficult tasks early on in the new campaign was to establish the campaign identity and agree on a campaign name. When making these decisions, in the forefront of the minds of many activists were the divisions that had plagued the AAC in the 1980s. To begin with, many disliked the campaign name 'Together for Yes', proposing alternatives. 'Yes for Repeal' was a name that had been informally discussed among different groups for some time; this had the support of many activists, particularly grassroots campaigners, as it connected with the work that they had done over many months and years to make the referendum a possibility ${ }^{31}$. However, it was not a name that connected with people outside of the movement and others felt that, like in the 1980s, the campaign required an identity that was inclusive of those who were not active or committed to the issue but still desired a change. 'Together for Yes' began to be the name that emerged. The campaign also felt that the name could be used to build a broad-based alliance that stood 'for' rather than 'against' something. For the co-directors, it was an inclusive concept, allowing disparate groups and individuals to come together on this single issue (Barron, 2019: 8).

Like the AAC in 1983, one of the key decisions for the campaign was the question of focus. The 2018 referendum campaign asked the electorate whether to remove the 8th Amendment from the constitution or not. From the beginning, it was evident to most campaigners that this had to be the focus and would be the key to the campaign's success and that if the campaign became bogged down in abstract legal and medical issues around abortion, it would lose (Griffin et al., 2019: 91-109). Unlike previous abortion rights activism in Ireland, campaigners this time began from the perspective that people were moveable on abortion. The campaigners understood that their key challenge was to convince voters, some of whom may have been personally against the idea of abortion, to support removing the constitutional ban on abortion in order to allow women to make these decisions for themselves. This was a significant and radical shift in abortion campaigning in Ireland and offers important insights for the global abortion movement. The focus on personal stories was the key tactic in achieving this as allowing women's own unmediated experiences of being denied an abortion in Ireland to be told would be central to shifting and re-framing the narrative of abortion. This decision would inform much of the campaign messaging and structure. As the campaign progressed, the TfY message was distilled into three key ideas:

- Enable women in Ireland to access abortion care at home,

- Allow doctors to treat women without fear of breaking the law or facing prosecution, and

- Support women to make important decisions about their families and pregnancies.

TfY messaging focused on access to 'abortion care' rather than on pro-choice language or reproductive rights messages. The campaign framed abortion as 'a healthcare need', placing it in the context of women's healthcare more broadly, and presenting abortion as a private matter between a woman and her doctor. The decision was influenced by focus group findings, which showed that this was the framing which resonated best with those who were undecided (see the Together for Yes, 'Messaging Book'). Multiple pieces of research confirmed that the electorate trusted mostly two groups of people to talk about abortion: women who have had an abortion, and doctors ${ }^{32}$. These ideas were then reflected in the poster and campaign slogan: 'Sometimes a private matter needs public support: Vote Yes'. As we will see below, this decision proved to be one of the more disputed aspects of the TfY strategy, particularly among those working and canvassing on the ground. This disquiet was also aired at the 'internal campaign organising day' which involved various groups and activists from around the country. However, despite these reservations, there was a powerful sense among activists that a unified and broad Yes campaign was essential to win the referendum.

TfY's core campaign message that abortion was a healthcare issue, between a woman and her doctor, saw doctors positioned front and centre in the campaign. TfY actively platformed doctors, promoting them for highprofile speaking roles. Individual doctors, including well-known gynaecologists and obstetricians, and healthcare providers, including the IFPA, also delivered campaign messages. The second core campaign strategy, as noted above, was the use of stories. Drawing on the experience of the Yes Equality campaign during the Marriage Equality referendum, the personal stories of women who had experienced abortion became a key driver of the campaign strategy. The public telling of personal, intimate stories was given a wider impetus with the emergence

\footnotetext{
${ }^{31}$ For a detailed discussion around the campaign name 'Together for Yes' see Griffin et al. (2019: 110-112).

32 See, for example, Red C poll commission by Amnesty International Ireland in 2016. Poll available at: https:/ / www.amnesty.ie/amnesty-internationalred-c-poll-reveals-irish-public-want-expanded-access-abortion-politicalpriority-incoming-government/
} 
of the global \#MeToo movement in the months before the referendum. Women across the island of Ireland and around the globe were telling painful stories, often for the first time, of abuse and sexual humiliations at the hands of men who all too frequently found protection in social and symbolic structures of power. For TfY, personal stories, rather than the theoretical and abstract arguments that characterised the AAC, chimed with the zeitgeist, reaching people with their immediacy and authenticity, and were essential to grounding the credibility and integrity of the campaign. This was also a strategy that found widespread support with the campaign's base of core activists. However, it is notable that the stories promoted in TfY campaign material were all carefully curated 'stories' of women's experiences of abortion that reflected the messaging of the campaign. For example, the stories of Paula and Deirdre appeared in one of the mid-campaign (late April/early May) TfY leaflets:

I am a 40-year-old mother of two teenage girls. Several years ago, I became pregnant unexpectantly by an emotionally abusive and manipulative partner. It was not a decision I made lightly, although I felt then (and still do) that it was the only option that I had that would lead to a positive outcome. I have never looked back and have no regrets (Paula, Dublin).

I was five weeks pregnant; it was Christmas week and we didn't have anyone to mind our children. I had an online consultation with a doctor. I was petrified the pills would be seized by customs. Christmas was hell. The pills arrived on $3^{\text {rd }}$ January, I continued bleeding for four days but didn't go to the doctor. I was so afraid that I just took the risk (Deirdre, Tipperary).

Paula's and Deirdre's stories emphasised how the 8th Amendment was a blunt instrument causing unnecessary pain and hardship, allowing the electorate to conclude that the 8th was incapable of addressing the complexity and nuance of women's lives and experiences during pregnancy. Both stories also involve women who were already mothers-a fact TfY were keen to highlight-emphasising how their individual decisions to have an abortion was a result of careful consideration and was, in fact, the responsible choice to make given their circumstances. In telling these stories, TfY was attempting to alleviate the concerns of what became known as the 'middle' voter, a person who was inclined towards supporting repeal but had concerns about it leading to 'abortion on demand', which was often a euphemism for irresponsible choices. While this strategy proved largely successful in that the referendum was won by a two thirds majority in a huge electoral turnout, it reinforced an implicit message that many activists operating on the ground were deeply unhappy with: that careful, restrictive legislation was necessary to ensure that abortion access was not 'abused'33.

The referendum on the thirty-sixth Amendment to the Constitution was held on 25 May 2018. The electorate voted by a landslide in favour of repeal. The scale of victory was enormous, with $66.4 \%$ of the electorate voting 'yes' to replacing Article 40.3.3 ${ }^{\circ}$ of the Constitution ('the 8th Amendment') with an article stating that provision may be made by law for the regulation of termination of pregnancy. At $64.5 \%$, the turnout was one of the highest ever recorded for a referendum in this country and the highest for any referendum since 1992. However, despite the scale of the support for the referendum, the government continued to insist that the draft legislation it had published before the referendum was not, as most activists assumed, a draft, but the final resolution. Although, as Mairead Enright notes, while the referendum question itself empowered politicians to make Irish abortion law, post-referendum, the government argued that people chad also voted indirectly on the legislation and it could not now be changed' (2018: 6). The government refused to any of the amendments that would alleviate the most burdensome aspects of the legislation and on the 1 January 2019, the Health (Regulation of Termination of Pregnancy) Act 2018 came into effect. Essentially, the legislation allows women and pregnant people to access abortion services under a number of strict conditions: where the pregnancy is less than 12 weeks; in cases where there is a risk to life, or of serious harm to the health of the pregnant person; and in cases where a condition would lead to the death of the foetus within 28 days of birth. The law is highly restrictive after 12 weeks with only a small number of abortions performed ${ }^{34}$. Nevertheless, over 6,500 women and pregnant people accessed abortion services in Ireland in 2019 and $2020^{35}$. For a country that had one of the most restrictive abortion regimes in the world, this is a significant political achievement and offers an important advancement in the struggle for abortion

\footnotetext{
${ }^{33}$ For an excellent analysis of the experiences of TfY campaigners on the ground and the occasional tensions between activists and the central TfY campaign, see Fitzsimons, 2021.

${ }^{34}$ For an overview of the operation and problems with the Health (Regulation of Termination of Pregnancy) Act of 2018, see Kennedy (2021).

35 6,666 abortions were performed in Ireland in 2019 and 6,577 abortions were performed in Ireland in 2020. See Department of Health (2020). Notifications in accordance with Section 20 of the Health (Regulation of Termination of Pregnancy) Act of 2018-Annual Report 2019. https://www.gov.ie/en/publication/b410b-health-regulation-of-termination-of-pregnancy-act2018-annual-report-on-notifications-2019/ (Department of Health, 2021). Notifications in accordance with Section 20 of the Health (Regulation of Termination of Pregnancy) Act of 2018-Annual Report 2020. https://www.gov.ie/en/publication/ ef674-health-regulation-of-termination-of-pregnancy-act-2018-annual-report-on-notifications-2020/
}

(C) 2022 by Author/s 
services in Ireland. Yet, it is a long way off from what many activists and campaigners envisioned the campaign achieving, namely free, safe and legal abortion with full decriminalisation. Figures from the Department of Health for England and Wales (2019/2020) reveal that the overly restrictive nature of Ireland's post-repeal abortion law still means that several hundred women and pregnant people continue to be forced to travel abroad to access abortion services ${ }^{36}$ and abortion campaigners must continue to organise for more meaningful access within Ireland itself.

\section{Campaign Criticisms}

Despite the arguments and debates within the wider Repeal campaign around strategy and tactics, the lasting impression exuded by the Repeal campaign was one of energy, enthusiasm, joy and optimism for social change, largely thanks to the thousands of volunteers, young and old, who devoted weeks and months to canvassing people in their homes and communities in every town and village in Ireland. However, it was these activists who most acutely felt the gap between the victory achieved and the actually quite restrictive legislative outcome. Thus, in the aftermath of the referendum campaign, several significant critiques of the TfY campaign have emerged. There was some tension between the campaign leadership and the local grassroots activists, who had devoted months to canvassing and knocking door-to-door (see Fitzsimons, 2021; Griffin et al., 2019: 117-135). Pro-choice activists did not care for TfY's moderate-style messaging around 'abortion care' and what they saw as the unwillingness of the campaign to criticise the government's proposed post-repeal legislation which was strictly regulated and failed to offer full decriminalisation ${ }^{37}$. The legal scholar and activist, Fiona de Londras, argues that the strategies employed by the TfY campaign 'reduced the space to acknowledge and support people who had "everyday" abortions; who did not fall into the "hard cases" categories' and that 'the right to choose was rarely discussed' to the point that there appeared 'to be a reluctance to insist in public discourse on autonomy and choice as fundamental to agentic reproductive life' (de Londras, 2020b: 125-6). This approach, arguably, had consequences later, making it difficult to effectively push back on the government's highly restrictive legislation that required a three-day waiting period and strict time limits. Another activist/academic Paola Rivetti (2019: 185) has argued that

$[\mathrm{t}]$ he strategy of pro-choice activists to focus on abortion narrowly, instead of approaching the issue of reproductive justice intersectionally, laid the foundations for the continuous invisibilisation in the law of those people who represent the 'Other' to the Irish population.

Rivetti correctly highlights the limitations of the referendum campaign and the failure to highlight how the restrictive nature of the new law would continue to disproportionately affect poor, marginalised women, in particular women of colour, women from ethnic minorities, migrant women and women living under the Direct Provision system ${ }^{38}$. What these criticisms rightly highlight are not just tensions that existed within the Repeal campaign, but contradictions that are evident more broadly within progressive campaigns where attempts are made to navigate a tightrope between a strategy of radical, transformative change and one of conciliation and managed change. These conflicts are a product not of organisation but of different political strategies for change.

\section{CONCLUSIONS}

Rosalind Petchesky, in her foundational study, Abortion and Women's Choice, identifies two sometimes contradictory ideological constituents within pro-abortion arguments which are products of different Western philosophical traditions (1990: 2-3). One set of arguments emphasises liberty and self-determination- in the idea that a person must be able to control their body and their reproductive choices. The second component stresses 'socially determined human needs' under the existing social division of labour; since the pregnant person is the

\footnotetext{
36375 travelled in 2019 and 194 travelled in 2020 (the lower figures for 2020 may reflect the travel restrictions imposed due to the Covid-19 pandemic). Source: Department of Health and Social Care UK (2020). National statistics: Abortion statistics for England and W ales: 2019. Published 11 June 2020. https:/ / www.gov.uk/government/statistics/abortion-statistics-for-englandand-wales-2020/abortion-statistics-england-and-wales-2020. Department of Health and Social Care UK (2021). National statistics: Abortion statistics for England and Wales: 2020. Published 10 June 2021. https://www.gov.uk/government/statistics/ abortion-statistics-for-england-and-wales-2019

${ }^{37}$ Some of these tensions are discussed in the three TfY co-directors' account of the referendum campaign, It's a Yes: How Together for Yes Repealed the Eighth and Transformed Ireland. For a more grassroots perspective, see McDonald et al. (2019); McGill (2019).

${ }^{38}$ Direct provision is the term used to describe the Irish state's reception system for people seeking asylum or the outcome of an international protection application. Amnesty International Ireland has described it in 2020 as 'an ongoing human rights scandal, trapping asylum seekers in limbo for years and violating their human rights' (https://www.amnesty.ie/directprovision/).
} 
individual most effected by pregnancy, it is they who must decide. In other words, pregnancy and reproduction are both individual and social, thereby creating a tension that societies struggle to resolve. As Petchesky writes:

we have to struggle for a society in which responsibility for contraception, procreation, and childbearing is no longer relegated to women primarily; and at the same time, we have to defend the principle of control over our bodies and reproductive capacities (2019: 3).

These elements are evidenced in the struggle for abortion rights in Ireland. The enormous and popular success of the Repeal movement, in many respects, appeared to be the embodiment of a successful feminist abortion campaign, yet the tensions reflected in this article haunted both the campaign and the aftermath. Nevertheless, the Irish Repeal campaign can provide much hope for the international struggle for abortion rights at a time when there are significant attacks on these rights. Repeal shows that it is possible to win a popular referendum campaign by centring the reproductive experiences and testimonies of women. However, it also acts as cautionary tale, warning pro-choice activists that tensions do not evaporate and the adoption of more liberal strategies comes with a cost.

\section{REFERENCES}

Barron, M. (2019). Learning from the 2018 Together for Yes Campaign. Available at: https://www.togetherforyes.ie/ app/uploads/2019/11/2019_TFY_Review.pdf (Accessed 01 August 2021).

Barry, U. (1992). Movement, change and reaction: The struggle over abortion rights in Ireland, in A. Smyth (ed), The abortion papers (pp. 107-118). Dublin: Attic Press.

Brown, J. (2019). Without apology: The abortion struggle now. London: Verso.

Bunreacht na hÉireann/Constitution of Ireland (1937). Available at: http://www.irishstatutebook.ie/ eli/cons/en (Accessed 30 November 2021).

Cacciaguidi-Fahy, S. (2005). The substantive issue and the rhetoric of the abortion debate in Ireland, in A. Wagner, T. Summerfield and S. F. Benavides Vanegas (eds), Contemporary issues of the semiotics of law (pp. 141-164). London: Hart.

Carnegie, A. and Roth, R. (2019). From the grassroots to the Oireachtas: Abortion law reform in the Republic of Ireland. Health and Human Rights, 21(2), 109-120.

Citizens' Assembly: The Eighth Amendment to the Constitution. (n. d.). Available at: https:/ /www.citizensassembly.ie/en/The-Eighth-Amendment-of-the-Constitution/The-EighthAmendment-of-the-Constitution.html (Accessed 1 August 2021).

Connolly, L. (2003). The Irish women's movement: From revolution to devolution. Dublin: Lilliput Press.

Connolly, L. and O’Toole, T. (2005). Documenting Irish feminisms: The second wave. Dublin: Woodfield Press.

Daly, C. (2015). Ireland's first abortion legislation, in C. Conlon, S. Kennedy and A. Quilty (eds), The abortion papers Ireland: Volume 2 (pp. 263-269). Cork: Cork University Press.

de Londras, F. (2020a). 'A hope raised and then defeated?' The continuing harms of Irish Abortion Law. Feminist Review, 124(1), 33-50. https:// doi.org/10.1177/0141778919897582

de Londras, F. (2020b). Intersectionality, repeal, and reproductive rights in Ireland, in S. Atrey and P. Dunne (eds), Intersectionality and buman rights (pp. 125-145). London: Hart Publishing/Bloomsbury. https://doi.org/10.5040/ 9781509935321.ch-006

de Londras, F. and Enright, M. (2018). Repealing the 8th: Reforming Irish Abortion Law. Bristol: Policy Press. https://doi.org/10.1332/9781447347545

Doherty, C. and Redmond, S. (2015). The radicalisation of a new generation of abortion rights activists, in C. Conlon, S. Kennedy and A. Quilty, A. (eds), The abortion papers Ireland: Volume 2 (pp. 270-274). Cork: Cork University Press.

Duffy, D. N. (2020). From feminist anarchy to decolonisation: Understanding abortion health activism before and after the repeal of the $8^{\text {th }}$ Amendment. Feminist Review, 124(1), 69-85. https://doi.org/10.1177/ 0141778919895498

Earner-Byrne, L. and Urquhart, D. (2019). The Irish abortion journey, 1920-2008. London: Palgrave Macmillan. https://doi.org/10.1007/978-3-030-03855-7

Edwards, E. and Flaherty, R. (2017). Thousands march against Eighth Amendment in Dublin, The Irish Times. 8 March. Available at: https://www.irishtimes.com/news/politics/thousands-march-against-eighth-amendment -in-dublin-1.3002375 (Accessed 01 August 2021).

Enright, M. (2018). 'The enemy of the good': Reflections on Ireland's new abortion legislation. Feminists@Law, $8(2), 1-12$.

Faludi, S. (1991). Backlash: The undeclared war against American women. New York: Three Rivers Press. 
Ferriter, D. (2009). Occasions of sin: Sex and society in modern Ireland. London: Profile.

Field, L. (2018). The abortion referendum of 2018 and a timeline of abortion politics in Ireland to date. Irish Political Studies, 33(4), 608-628. https://doi.org/10.1080/07907184.2018.1500461

Fitzsimons, C. (2021). Repealed: Ireland's unfinished fight for reproductive rights. London: Pluto Press. https://doi.org/ $10.2307 /$ j.ctv23hcfms

Goodman, A. (2018). Meet two of the activists behind Ireland's historic vote to repeal a ban on nearly all abortions. Democracy Now! 30 May. Available at: https://www.democracynow.org/2018/5/29/meet_two_of_the_activists _behind (Accessed 01 August 2021).

Gordan, M. (1984). Fighting for control-The ongoing struggle for reproductive rights, in The Irish feminist review 84 (pp. 7-37). Dublin: Women's Community Press.

Griffin, G., O'Connor, O. and Smyth, A. with O'Connor. A. (2019). It's a yes: How together for yes repealed the eighth and transformed Irish society. Dublin: Orpen Press.

Haughey, C. 1979. Dáil Éireann Debate. Wednesday, 28 February, 312 (3). Available at: https:/ /www.oireachtas.ie/en/debates/debate/dail/1979-02-28/3/ (Accessed 01 August 2021).

Heskett, T. (1990). The second partitioning of Ireland. Dublin: Brandsma Books.

Holland, K. (2013). Savita: A tragedy that shook a nation. Dublin: Transworld.

Hug, C. (1999). The politics of sexual morality in Ireland. London: Macmillan. https:// doi.org/10.1057/9780230597853

Inglis, T. (2003). Truth, power and lies: Irish society and the case of the Kerry babies. Dublin: UCD Press.

Irish Women United. (1971). Chains or changes? The civil wrongs of Irish women.

Kennedy, S. (2020). The right to know: Gender, power, reproduction and knowledge regulation in Ireland, in P. Cullen and M. P. Corcoran (eds), Producing knowledge, reproducing gender: Power, production and practice in contemporary Ireland (pp. 110-129). Dublin: UCD Press.

Kennedy, S. (2021). Accessing abortion in Ireland: Meeting the needs of every woman. National Women's Council. Available at: https://www.nwci.ie/images/uploads/15572_NWC_Abortion_Paper_WEB.pdf (Accessed 01 August 2021).

Lord, S. (2015). The eighth amendment: Planting a legal timebomb, in C. Conlon, S. Kennedy and A. Quilty (eds), The abortion papers Ireland: Volume 2 (pp. 90-103). Cork: Cork University Press.

McCann, E. (2016). People have the power. Hot Press, 05 May. Available at: https://www.hotpress.com/ opinion/people-have-the-power-17224763 (Accessed 01 August 2021).

McDonald, N., Antosik-Parsons, K., Till, K. E., Kearns, G. and Callan, J. (2019). Campaigning for choice: Canvassing as feminist pedagogy, in K. Browne and S. Calkin(eds), After repeal: Rethinking abortion politics (pp. 124-143). London: Zed. https://doi.org/10.5040/9781350218284.ch-007

McGill, M. (2019). Enough judgement: Reflections on campaigning for repeal in rural Ireland, in K. Browne and S. Calkin (eds), After repeal: Retbinking abortion politics (pp. 109-123). London: Zed. https://doi.org/10.5040/ 9781350218284.ch-006

Muldowney, M. (2015). Breaking the silence: Pro-choice activism on Ireland since 1983, in J. Redmond, S. Tiernan, S. McAvoy and M. McAuliffe (eds), Sexual politics in modern Ireland (pp. 127-147). Dublin: Irish Academic Press.

Mulhall, A. (2015). The republic of love. Critical Legal Thinking, 23 June. Available at: https:// criticallegalthinking.com/2015/06/23/the-republic-of-love/ (Accessed 01 August 2021).

Murphy, M. (2009). History of the pro-choice movement in Ireland 1980's to 2009 [Audio]. Maynooth Sociology Society Meeting. 24 April. Available at: https://www.mixcloud.com/workerssolidarity/history-of-the-pro-choicemovement-in-ireland-1980s-to-2009/ (Accessed 01 August 2021).

O'Donnell, A. (1982). Letter to the editor, The Irish Times, 29 July.

O'Reilly, E. (1992). Masterminds of the right. Dublin: Attic Press.

O’Toole, F. (2014). Why Ireland became the only country in the democratic world to have a constitutional ban on abortion, in The Irish Times, 26 August. Available at: https://www.irishtimes.com/news/politics/why-irelandbecame-the-only-country-in-the-democratic-world-to-have-a-constitutional-ban-on-abortion-1.1907610 (Accessed 01 August 2021).

Petchesky, R. (1990). Abortion and women's choice: The state, sexuality and reproductive freedom. Boston: Northeastern University Press.

Reidy, T. (2019). The 2018 abortion referendum: Over before it began! in K. Browne and S. Calkin (eds), After repeal: Retbinking abortion politics (pp. 21-35). London: Zed. https:/ / doi.org/10.5040/9781350218284.ch-001

Riddick, R. (1990). The right to choose: Questions of feminist morality. Dublin: Attic Press.

Rivetti, P. (2019). Race, identity and the state after the Irish abortion referendum. Feminist Review, 122(1), 181-188. https://doi.org/10.1177/0141778919845881

Sanger, C. (2017). About abortion: Terminating pregnancy in twenty-first century America. Cambridge, MA: Harvard University. https://doi.org/10.4159/9780674977297 
Sheldon, S. (2016). How can a state control swallowing? The home use of abortion pills in Ireland. Reproductive Health Matters, 24(48), 90-101. https://doi.org/10.1016/j.rhm.2016.10.002

Side, K. (2020). Abortion im/mobility: Spatial consequences in the Republic of Ireland. Feminist Review, 124(1), 1531. https://doi.org/10.1177/0141778919894891

Smyth, A. (1992 [2015]). The abortion papers Ireland: Volume 1. Cork: Cork University.

Smyth, A. (1993). The women's movement in the Republic of Ireland 1970-1990, in A. Smyth (ed), Irish women studies reader (pp. 245-269). Dublin: Attic Press.

Smyth, A. (2002). Interview with Ailbhe Smyth. Tall Girl Shorts. Available at: http://www.tallgirlshorts.net/ marymary/ailbhe.html (Accessed 01 August 2021).

Spillane, A. (2015). The impact of the crisis on Irish women, in C. Coulter and A. Nagle (eds), Ireland under austerity neoliberal crisis, neoliberal solutions (pp. 151-169). Manchester: Manchester UP. https://doi.org/10.7765/ 9781784997120.00014

Together for Yes. (n. d.). Messaging book: Version 2. April 2018 [Unpublished].

Women on Waves. (2001). Letter to the editor, in The Irish Times, 25 June. Available at: https://www.irishtimes.com/opinion/women-on-waves-1.314733 (Accessed 01 August 2021).

Women on Waves. (2001). Abortion ship Ireland 2001. Available at: https://www.womenonwaves.org/ en/page/769/abortion-ship-ireland-2001 (Accessed 01 August 2021).

X and McDonagh, S. (1992). The Attorney General v. X and Others: Judgments of the High Court and the Supreme Court with submissions made by counsel to the Supreme Court. Inc. Council of Law Reporting for Ireland.

Citation: Kennedy, S. (2022). A Tale of Two Referendums: A Comparative Study of the Anti-Amendment Campaign and Together for Yes. Feminist Encounters: A Journal of Critical Studies in Culture and Politics, 6(1), 04. https://doi.org/10.20897/femenc/11748

Copyright (C) 2022 by Author/s and Licensed by Lectito BV, Netherlands. This is an open access article distributed under the Creative Commons Attribution License which permits unrestricted use, distribution, and reproduction in any medium, provided the original work is properly cited. 